Kaygı, 18(1)/2019: 154-171. Araştırma Makalesi | Research Article

Makale Geliş | Received: 20.12.2018

Makale Kabul | Accepted: 14.02.2019

Yayın Tarihi | Publication Date: 15.03.2019

DOI: $10.20981 /$ kaygi.529822

Cem ÖZKURT

Dr. Öğr. Üyesi | Assist. Prof. Dr. Bayburt Üniversitesi, İnsan ve Toplum Bilimleri Fakültesi, Sosyoloji Bölümü, Bayburt, TR Bayburt University, Faculty of Humanities and Social Sciences, Department of Sociology, Bayburt, TR

ORCID: 0000-0003-1438-6517

ozkurtcem70@hotmail.com

\title{
Toplumsallık, Anlam ve Bir Sosyal İnşa Olarak İnsan
}

$\ddot{\mathbf{O} z}$

Sosyal olarak inşa edilmiş toplumsal gerçekliğin simge, sembol ve anlam ağları, toplumları ve bireyleri bilişsel düzeyde biçimlendiren ve şekillendiren sosyo-psişik örüntülerdir. $\mathrm{Bu}$ örüntüler, toplumsal etkileşim düzeni içinde, güç ilişkileriyle iç içe geçerek, farklı türden formlar alırlar ve kompozisyonlara bürünürler. Etkileşim düzeni içerisinde, bu kompozisyonlarla farklı düzeylerde toplumsal karşılaşmalar deneyimleyen bireyler; simge, sembol ve anlam ağlarının karşılıklılığıyla biçimlenen sosyal konfigürasyonlarla inşa edilirler ve yeniden inşa edilirler. Bu inşalar, bireyleri hissediş, düşünüş ve davranım düzeylerinde biçimlendirir ve onlara toplumsal oluşun dinamikleriyle şekil alan bir kimlik verir. Bu çalıșma, toplumsal olarak inşa edilen insanın; simge, sembol ve anlam ağlarıyla karşılıklı etkileşim sonucunda oluşan ve olgunlaşan bir yaratı olduğu tezini önemle vurgulamaktadır. Bu vurguyu yaparken, sosyolojinin ve antropolojinin kuramsal birikimlerinden olabildiğince yararlanmakta ve sosyal bilimsel muhakemeyi öne çıkaran bir analizi gerçekleştirmeye çalışmaktadır.

Anahtar Kelimeler: Toplumsallık, Sembol, Anlam.

\section{Society, Meaning and Human Being as a Social Construction}

\begin{abstract}
Symbols, symbolic codes and meaning patterns of socially constructed social reality are socio-psychic patterns that shape and shape societies and individuals at the cognitive level. These patterns, within the framework of social interaction, are intertwined with power relations and take forms of different kinds and take on compositions. Individuals experiencing different levels of social encounters in these interactions, with these compositions; they are constructed and rebuilt with social configurations that are shaped by the reciprocity of symbols, symbols, and meaning networks. These constructions shape individuals in the levels of feeling, thinking and behavior, and give them an identity shaped by the dynamics of social existence. This work, socially constructed people; it emphasized the thesis that there is a creation and maturation as a result of mutual interaction with symbol, symbol and meaning networks. In making this emphasis, it takes advantage of the theoretical accumulations of sociology and anthropology and tries to carry out an analysis that emphasizes social scientific reasoning.
\end{abstract}

Keywords: Socialization, Symbol, Meaning. 


\section{Giriș}

Klasik sosyoloji kuramcıları, toplumsal oluşun dinamiklerini sistematik olarak tahayyül etmeye başladıklarında, toplumsallığın sui generis (kendine özgü) karakterini bir soyutlamadan ya da a priori bir felsefi ilkeden hareketle analiz edemeyeceklerinin farkında olmuşlardır. Toplumsallığın bileşenlerini keşfetmek için klasik sosyolojisinin bulduğu çözüm, karşılıklı bağımlılıklar içinde yapılaşmış ve bireylerin biyografik yaşantılarından daha uzun süreli olan kurumsal düzenliliklere konsantre olmak biçimindedir. Örneğin, Durkheim, toplumun hem kendisini hem de dış dünyayı tahayyül ediş biçimlerine anlam verme sürecinde, dikkat edilmesi gereken noktanın bireyin doğas1 değil, toplumun doğası (1994: 22) olduğuna vurgu yapmaktadır. Durkheim’a göre insan iki bilinçten teşekkül eder. İlki, bireysel bilinçtir ve tekil olarak bireyleri belirler. İkincisi ise, tüm toplum için ortaklaşa durumları temsil eden ve simgelere gönderme yapan kollektif bilinç alanıdır (2006: 137). Durkheim, öz olarak, "insanla hayvan arasındaki en temel farkı insan organizmasının manevileşmesinde" görmektedir. Toplum, bireyin doğasını besleyip zenginleştirirken, bir yandan da bireyleri kendine tabi k1lmaktadır (2006: 39). Weber ise daha ilk kertede, sosyolojiyi, toplumsal davranışın inşa süreçlerini açıklamaya çalışan ve yorumlamacı anlamaya (verstehen) olanak veren bir bilim (Coser 2011: 204) olarak tanımlamıştır. Weber'in projesi, bireylerin kendi davranışlarına verdikleri öznel anlamlandırmaların boyutlarını keşfetmektir (Aron 2014: 355). Weber'e göre sosyal bilimlerin amacı, toplumsal gerçekliğin biricikliğini kavramaktır (Giddens 2014: 224). Marx'ın konumlanması ise toplumsal dinamiklerin özgül meydana geliş içeriklerinin üretim ilişkileriyle süreklilik çizgisini göstermek biçimindedir. Kapitalist işleyiş içindeki birey, anlam haritalarını,

alg1 kategorilerini ve dünya görüşünü, zorunlu ve kaçınılmaz olarak doldurduğu sınıf durumuyla ilişkisinde inşa etmektedir. Marx'a göre kapitalizmin temel yapısal karakteristiği sermaye ve ücretli emek arasındaki dikatomik sınıfsal çelişkiyle biçimlenmektedir (2014: 54). Dikatomik sınıfsal belirlenme "kendi için" sınıfa, pratik 


\section{Cem ÖZKURT, “Toplumsallık, Anlam ve Bir Sosyal İnşa Olarak İnsan,” Kaygı, 18(1)/2019: 154-171.}

eylem programı dayatan bir praksis öngörmektedir ve tarihsel/ toplumsal oluşun tamamlanması, insana yüklenen dönüştürücü bu misyonla olanaklı hale gelmektedir.

Batı sosyolojisinde, anlamı toplumsal kökleriyle, bir toplumsal analiz biçimi olarak ortaya koyma eğilimi, Marx ve Weber'le birlikte tarihsel bir karaktere bürünmüştür ve anlamın inşa ediliş, biçimleniş aşamaları tarih içi dinamiklerle açıklanmıştır Ancak, insanın toplumsal anlam kökenlerinin ayrıntılarına bakmak, insanı ve toplumu oluşturan, ona form ve biçim veren kurucu sosyo-psişik örüntüleri ortaya koymakla olanaklı hale gelmiştir. Bu örüntüler, bireyleri mana, düşünme, hissediş ve tahayyüller düzeyinde belirleyen simgeler, semboller ve anlamlandırmalar gibi kök inşalardan oluşmaktadır. Simge, sembol ve anlamlandırmalardan teşekkül eden kök inşalar, bireylerin biyografik yaşantılarından öte ve tarihsel karakterli olmaları dolayısıyla, özneyle ilişkilerinde göreceli bir dışsallığı yani ayrıksı bir dış evreni temsil etmektedir. Buna karşıllk benlik, zihin ve hafıza ise öznenin kendine içkin evrenini oluşturmaktadır. $\mathrm{Bu}$ ayrımlama, 1930'larda Mead'in, benliğin gelişiminin arka planlarını keşfetmeye yönelik girişimlerinde farklı bir form ve kuramsal uzam almıştır. $\mathrm{Bu}$ yorumda, bireyler, gündelik yaşantılarında, birey olarak kendilerini kurgularken, aynı zamanda da toplumsal olarak inşa edilmektedirler ve bu inşalar, toplumsal oluşun dinamiklerini biçimlendiren sosyal simge ve işaretlerin anlam ağını içselleştirmeye yönelik yatkınlıkları geliştirmektedir. $\mathrm{Bu}$ çerçevede, içselleştirilmiş yatkınlıklar, sosyalizasyon ve yeniden sosyalizasyon süreçlerinde kilit rol oynayarak, toplumsal alanda birikmiş sosyal uzlaşmaların değerler, simgeler ve anlamlar düzeyindeki örüntülerinin aktörlerdeki geçişkenliklerine aracılık etmektedir.

1970'lerde Geertz'in antropolojik çalışmaları simge, sembol ve anlam ağında gelişen / olgunlaşan ve sosyal olarak inşa edilmiş insan nosyonuna yeni bir boyut ve içerik kazandırmıştır. Geertz’e göre düşünmek, zihin içindeki gerçekleşmelerden değil de, çoğu zaman jestler, çizimler, müzikal sesler, saat gibi mekanik gereçler ya da mücevherler gibi doğal nesneler arasındaki bir trafiğin (Geertz 2010: 64) ürünü olarak ortaya çıkmaktadır. Kültürel kalıplar anlamlı simgelerin örgütlü dizgeleridir (2010: 65) 
ve insan kendini sadece kültür yoluyla hatta kültürün çok özel biçimleriyle tamamlayan (2010: 68) bir yaratıdır. Geertz'in yorumunda, zihin içindeki tahayyüllerle, dünya durumlarındaki pratikler arasında var olan tekabüliyetler, anlam ağında biçimlenen insanın antropolojik arka planını oluşturmaktadır. Geertz, düşünme, kavramlaştırma, formülleştirme, kavrama, anlama ya da buna benzer şeylerin, zihin içindeki hayalet benzeri oluşumlardan değil, simgesel modelin durum ve süreçlerinin dünyadaki durum ve süreçlerle uyuşmasından oluştuğunu (2010: 244) ifade etmektedir. Geertz, diş dünyadaki simgesel sıralanış ve vaziyet alışlarla, zihnin kendi içindeki muhakeme ve müzakere süreçlerinin paralelliğini, Endonezya'da yaşayan Bali yerlilerinin horoz döğüşlerini gözlemleyerek analiz etmiştir. Geertz, Bali yerlilerinin horoz düğüşünü “erk tüketiminin popüler bir saplantısı" olarak değerlendirir. Bali yerlilerinin organize ettikleri horoz döğüşleri, sıradan bir eğlence olmanın çok ötesinde, toplumsal hiyerarşinin ve güç ilişkilerinin bir arenasıdır. Geertz'e göre horoz döğüşlerinde, bahisler oynanır ve döğüşün gerçekleştiği arenaya en yakın olan kişiler, aynı zamanda Bali toplumunun da merkezinde olan kişilerdir. Bu kişilerin merkez olma durumları, toplumdaki para ve statü ilişskilerindeki yüksek konumlarıyla bağlantılıdır. Bali toplumunun sosyo/ekonomik sınıfsal merkezi, horoz döğüşünün de erksi hazzının duygu merkezini oluşturmaktadır. Horoz dögüşünün heyecanı ve tutkusu, ilk kertede, döğüşü en yakından izleyen merkezdekiler tarafından belirlenmektedir. Merkezdekiler, bahisleri en yüksekten açmaktadır ve hangi horozun ölüp, hangi horozun yaşayacağına ilişkin ön deyi, "statü için bir kan gölüne" dönüşmektedir. Merkezin dışında, dögüsşü takip eden çevrede ise kişilerin ve grupların oynadıkları bahisler merkezdekileri geçememektedir ve hiç kimse kendi köyünün, muhitinin ve tanıdığının horozunun rakibine para yatırmamaktadır. Horozlardan biri mutlaka ölecektir ve bu seyirlik durumun en görkemli coşkusu, dögüşü en önde izleyen merkezdekiler (hem sosyo/ekonomik sınıfsal merkez, hem de döğüşü en yakından izlemek bakımından merkez) tarafından yaratılmaktadır ve çevrenin tutkusu ve erksi heyecanı, merkeze göre konum almaktadır. Bu çerçevede, Bali yerlilerinin horoz döğüşü, sadece iki horozun birbirleriyle kavgaya tutuşmaları değil, toplumun güç merkezlerinin boy gösterdiği bir 


\section{Cem ÖZKURT, “Toplumsallık, Anlam ve Bir Sosyal İnşa Olarak İnsan,” Kaygı, 18(1)/2019: 154-171.}

arena ve derin oyunun icra edildiği mekânsal bir bütünlüktür (2010: 446-490). Bu yaklaşımın zihin ile dünya durumlarının anlam içerikli tekabüliyetini öne çıkaran analizi, bu makalenin tartışmaya çalıştığı: bireylerin simge, sembol ve anlam ağlarının toplumsal güç ilişkilerine gömülü gerçekliğinde sosyal olarak inşa edildikleri tezine temel bir çıkış noktası sağlamaktadır. Bu yönlü bir çabanın kuramsal arka planına, diğer önemli katkı, Bourdieu'nun simgesel sermaye ve sembolik güç nosyonlarından gelmektedir. Bourdieu, simge, sembol ve anlam örüntülerine, Geertz'in horoz döğüşü analizine yakın bir bağlamda, toplumsal uzamda inşa edilen sembolik gücün varyasyonları çerçevesinde bakmaktadır. Bourdieu'ya göre sembolik güç bireyler üzerinde fiziksel kuvvet kullanmadan işlevsel olan büyülü bir güç biçimidir ve bireylerde gömülü olan yatkınlıklardan kaynaklanmaktadır. $\mathrm{Bu}$ yatkınlıklar ise insanların zihinlerine ve bedenlerine işlenen tabiyetlerden inşa edilmektedir (Bourdieu 2015: 54). Simgesel düzen, sağlamlılığını tutarlı ve sistemli dizgelerle biçimlenmiş olmasına ve dünyanın nesnel yapılarına, yine nesnel olarak bağlanmış durumda bireylere dayatılmasıyla (Bourdieu 2006: 118) inşa edilmektedir.

Bourdieu, sembolik sermayeyi saygınlık, itibar ve bilinirlik anlamında şeref, dolayısıyla tanıma ve ikrar temelli bir sermaye biçimi (2016: 58) olarak tanımlar. Çıkar ve fayda yönelimli homo economicus failliğini ise sosyal uzamda, biyolojik libidodan, toplumsal libidoya dönüşen bir süreç olarak betimler:

Toplumbilimin çabalarından biri de, toplumsal dünyanın farklılaşmamış bir itki olan biyolojik libido'yu, özgül, toplumsal libido olarak oluşturduğunu anlamaktır. Gerçekten de, ne kadar alan varsa, o kadar da libido vardır: Libido'nun toplumsallaşma işi, tam da itkileri özgül çıkarlara, ancak içinde kimi şeylerin önemli, diğerlerinin önemsiz olduğu bir toplumsal uzamla bağıntı içinde ve bu uzamdaki nesnel farklılıklara tekabül eden farklılıkları getirebilecek biçimde oluşmuş, toplumsallaşmış eyleyiciler için var olan, toplumsal olarak çıkarlara dönüştüren şeydir (2006: 141).

Bourdieu, sembolik iktidar, homo economicus, simgesel düzen gibi tunçtan yasaları çağrıştıran, toplumsal olarak da yasalı gibi gözüken sıralanmaların ve dizgelerin, bizzat bu sıralanmaları ve dizgelenmeleri ayakta tutan ve işlevsel kılanların en kudretli sosyal düzen kurucular olduğunu vurgular. Söz konusu düzen, aslında 
tunçtan yasaların ürünü değil de; sofistike bir sosyal inşadır ve simge, sembol / anlam örüntülerinin eyleyicilerin benliklerinde yatkınlıklar biçiminde ince ince işlenmesinin sonucudur. Bu çerçevede Bourdieu, gündelik akış içerisinde bireyleri saran, varlıklarını zorla dayatan sosyo-ekonomik ve sınıfsal dışsal/ nesnel gerçekliklerin, simgesel düzen aracılığıyla bireylerin içine gömülü habituslarda ${ }^{1}$ saklı ve gizli konfigürasyonlarla var olduğunu ve sırf bu nedenden dolayı kendisini ispata gerek duymaksızın bireyleri eyler duruma getirdiğini vurgular. Simgeler, semboller ve anlamlar, bireylerin toplumsal yatkınlıklarını içeren habituslarda saklıdır ve her birey kendi gerçekliğinde sermayelerinin dağılımıyla, alanlarda mevcut konumlarını güçlendirmek için bir mücadele dünyasının içerisine girmektedir.

\section{Toplumsal / Anlamsal İçerikler ve Bilişsel Konumlanmalar}

Bireylerin gündelik olay ağlarına ve sıradan olup bitmelere yükledikleri anlamlarla, onların genel hayat vaziyetleri ve bilişsel konumlanmalarının, toplumsallıkla olan özel türden ilişkisi ve geçişkenlikleri sorunsalı, hem sosyal psikoloji hem de mikro sosyoloji içerisinde uzun bir tartışma geleneğine sahiptir. Bu tartışma geleneği içerisinde şüphesiz ki çı̆̆ır açan yorumcular arasında G. H. Mead'in önemli bir yeri vardır. Mead, kuramsal girişiminin çıkış noktasını şöyle ifade etmiştir: "Birey kendi içinden çıkıp, kendisini bir nesne olarak görmeyi nasıl başarı»" (2017: 167). Mead'in böyle bir sorunsallaştırmayla işe başlaması aynı zamanda, benliğin gelişiminin arka planlarını analiz etmeye yönelik bir girişime de olanak vermiştir.

Mead, "bireyin kendi içinden çıkıp, kendisini bir nesne olarak görmeyi” oyun ve grup içinde oyun aşamalarıyla gerçekleştirdiğini iddia eder. Oyun aşamasında çocuk, yaşamına giren unsurların sadece rolünü alır. Tek boyutlu bir alımlama zamanla tavırların sadeleşmesiyle ve farkların silinmesiyle sonuçlanır. Grup içinde oyunda ise kişi, ortak aktiviteye katılan herkes olur ve ortak aktiviteye katılan herkesin rolünü alır.

1 Bourdieu'ya göre "Habitus", faillerin / eyleyicilerin içine işleyen yapılandırıcı bir mekanizma, toplumsallaşmış bir öznelliktir (2015: 47, 116). 


\section{Cem ÖZKURT, “Toplumsallık, Anlam ve Bir Sosyal İnşa Olarak İnsan,” Kaygı, 18(1)/2019: 154-171.}

Böylece "genelleştirilmiş ötekinin” rolünü almış ve tavrını takınmış olur. Genelleştirilmiş ötekinin rolünü almak aynı zamanda toplumsal oluşun dinamiklerini biçimlendiren anlam ağlarını içselleştirmeye yönelik yatkınlıkları geliştirir (2017: 178188).

Toplumsal anlam ağlarının içselleştirilmesinde dil, en kritik rolü oynar. Sosyal olarak inşa edilmiş toplumsal gerçekliğin simge ve anlam örüntüleri dil aracılığıyla geçmiş, bugün ve gelecek arasında diyalektik bir mana bütünlüğü oluşturarak tarihselleşir. Bireyler açısından bu işleyiş, ezbere gerçekleşen süreçlerle pratiğe yansımaz. Gündelik akış içerisinde bireyler, tek tek olaylardan, anlardan ve durumlardan tipleştirmelere giderler. Bu tipleştirmeler, birer kategorileşme olarak inşa edilir ve kodlanır. Bu kodlamalar sonucunda tipleştirmeler, ahbablardan çağdaşlara anonimlik kazanır (Berger ve Luckmann 2008: 44-51). Yani aslında, bir imge ortaya çıktığ1 yerden ve zamandan koparılarak saklanır (Berger 2013: 10) ve ahbablardan çağdaşlara, şimdiki zamandan gelecek zamana ardışıklık kazanarak uzanır. Böylece, bireylerin anlamsal "kök inşalarının" gerçekleştiği sosyo-psişik ve tarihsel alg1 kategorileri anlama dayalı bağlamlar içinde inşa edilmiş olur.

$\mathrm{Bu}$ noktada, bazı temel sorunsallar dizisini gündeme getirmekte fayda vardır: "Söz konusu algı kategorileri gündelik akış içerisinde nasıl etkin hale gelmektedir ve işlevsel kimliğe bürünmektedir. Bireylerin toplumsal oluşumdaki simge ve sembol temelli örüntüleri tanıma ve tercüme etme mekanizmaları nasıl işlemektedir?” Böyle bir sorunsallar setine, Erwing Goffman'ın kavramsal çerçevesinde, ilk olarak, alg1 kategorileri, kurucu anlamlandırmalar ya da kök inşaların, işaret ettikleri toplumsal bağlamlarda karşılaşılması muhtemel kişi kategorilerini sabitlediklerine vurgu yapılır. Verili toplumsal bağlamlardaki sosyal ilişki rutinleri, karşımıza çıkan ötekilerle karşılaşma anları yaratmaktadır $\mathrm{Bu}$ karşılaşmalarda, kişilerin görünüşlerinden ve niteliklerinden "ne menem bir şey olduklarına dair" bir izlenim geliştirir ve geriye dönük muhakemeler yaparız (Goffman 2014: 28). 
Goffman, bu muhakemelere "varsayılan toplumsal kimlik" adını verir. Kişilerin gerçekten mensup oldukları kategoriler ve sıfatlar ise onların "fiili toplumsal kimliğini" oluşturur. Toplumsal yaşantıda, bu değerlendirme ve muhakeme süreçleri sonunda bireylerin iyi, kötü, işe yaramaz, tehlikeli, sağlıksız, lekeli, yetersiz gibi damgalanma süreçleri “toplumsal kimlik” kavramıyla ilişkisinde inşa edilir (2014: 29). Goffman'ın "damga idaresi" kavramı ise damganın belirli türden ötekiler için steotipleşmesi ve kategorileşmesine gönderme yapar (2014: 88). Böylece bireyler, ötekilere ilişkin tutumlarını belirli türden formlar içinde tipleştirirler.

O halde, şu ana kadar iki tipleştirme yada kategorileştirme türüyle karşılaştığımızı söyleyebiliriz. Bunlardan ilki, bir imgenin ortaya çıktığı yerden ve zamandan koparak geçmiş, bugün ve geleceği de içerecek biçimde ardışıklık kazanması ve ahbablardan çağdaşlara uzanmasıdır. İkincisi, bireylerin gündelik yaşantıda "ne menem bir şey olduklarına" dair izlenimlerin belirli türden ötekiler için steotipleşmesi yani kategorileştirilmesidir. Bu çerçevede düşünüldüğünde, iki biçimli ya da çift yönelimli bir simge, sembol ve anlam ağının biçimlenmesinden söz edilebilir. İlki, bir ve birden fazla kolektif yaşanmışlı̆ı̆ı, deneyimlemenin ve durumsallığın imlenmesi ve bu imlemenin tarihsel karakter kazanarak bireylerin biyografik yaşantılarından daha uzun süreli olarak bireyler dünyaya geldiklerinde bu imgelerin anlamsal göstergelerinin hala hazırda kurulu olmasıdır. İkincisi ise bir dizi toplumsal süreç sonucunda ötekinin işaretlenmesi ve damgalanmasının, var olan pratik işleyiş ve edimler dünyasıyla eş güdümlü olarak biçimlenmesidir. Burada, benliğin oluşumu, benliğin toplumsallıkla ilişkisinde, güzel/çirkin, uzun/kısa, bilgili/cahil, iyi/kötü, yeterli/yetersiz, güçlü/zayıf gibi zıt ve çelişen anlamsal içeriklerle ve özellikle de sempati / antipati aktlarıyla inşa edilmesidir. Bu zıt ve çelişen inşaların biçimlenmesinde toplumsallı̆̆n güç ilişkilerine gömülü unsurlarının hangi düzeylerde yönlendirici olduğu ve kurucu rol üstlendiği ayrıca kritik edilmesi gereken önemli bağlamlardan biridir. 


\section{Toplumsal Gücün Difüzyonu ve Simgesel Düzen}

Goffman'ın damga ve damga idaresi kavramlarıyla vurguladığı ve toplumsal karşılaşmalardan doğal olarak çıkan yakınsamaların ve dışlamaların, bir dizi toplumsal sürekliliklerin, sıralanmaların ve tutarlılıkların ürünü olduğu ve eskimez bir biçimde toplumsal gücün dağılımıyla ve bu dağılımdan oluşan olgusallığın simgesel düzen biçiminde işleyişi, Bourdieu sosyolojisinin temel argümantasyonlarından biridir. Bourdieu, bu süreklilikleri Hume'un sorduğu bir soruya atıfla gündeme getirir: "yönetenler o kadar az sayıda, yönetilenler ise bu kadar kalabalıken, yani sayı üstünlüğünü ellerinde bulundururlarken, toplumsal düzen nasıl bu kadar rahatça korunabilmektedir" (Bourdieu 2015: 200).

Hume’un sorduğu bu nitelikte bir soruya, Bourdieu'un cevabı, güç ilişkilerinin sembolik boyutlarını anlamadan, gerçekte işleyen güç ilişkilerinin anlaşılmasının mümkün olamayacağı biçimindedir. Bourdieu' ya göre "güç ilişkileri, sadece fiziksel, askeri hatta iktisadi ilişkilerden ibaret olsaydı, kuvvetle muhtemeldir ki çok daha kırılgan ve kolayca tahrip edilebilir olurlardı” (2015: 200). Kapitalist toplumda güç ilişkilerinin sağlamlığını ve tahkim edici karakterini, Bourdieu'dan önce Althusser, devletin siyasal ve ideolojik aygıtlarının, kurulu düzenin kurallarına boyun eğilmesinin yeniden üretimini gerçekleştirmesi ve üretim ilişkilerinin yeniden üretiminin sağlama alınması bağlamında vurgulamıştır (Althusser 2014: 144). Althusser, kapitalist sistemin bireylerin vicdanlarında her gün her saniye sağlama alındığını ve ideolojinin herkesin arkasına birer inzibat takmaya gerek kalmadan bireyleri eyler duruma getirdiğini (2014: 135-136) ifade etmektedir.

Bourdieu da Althusser'e yakın bir mahiyette sosyal gerçekliğin inşa edici baş aktörünün devlet olduğu düşüncesindedir (2015:206 ). Toplumsal sistemin sembolik bir tahakküm biçiminde dayatılması bir devlet geleneğiyle ilintilidir ve bu tarihsel bir düzenlilikle karşımıza çıkmaktadır (2015: 210) Bourdieu'ya göre bu düzenlilikler, devlet ile kurumsallaşma ritüelleri arasındaki bağlantıda gizlidir ve devlet toplumsal düzeni yapılandırarak toplumsal gücün dağıtımını, bölüşümünü, yayılımını ve 


\section{Cem ÖZKURT, “Toplumsallık, Anlam ve Bir Sosyal İnşa Olarak İnsan,” Kaygı, 18(1)/2019: 154-171.}

taksimatını gerçekleştirmektedir. Simgesel düzen, bu köklü yapılandırmada, şeylerin o haliyle olduğunun itirazsız biçimde kabul edilmesine, hatta başka türlü olamayacağına, en akılsallaşmış biçiminin / halinin bu olduğuna hükmeder ve bireylerin benliklerinde bu hükmü meşrulaştırır.

Örneğin, Bourdieu ve Passeron'un “Yeniden Üretim” isimli çalışmalarında, “her pedagojik eylemin, kültürel bir keyfiyetin, keyfi bir iktidar tarafından dayatılmasını içermesinden ötürü objektif olarak sembolik bir şiddete" (2015: 35) dönüştügünü ifade etmeleri, objektif olarak işleyen sembolik şiddetin, pedagojik ve tedrisi süreçlerin her aşamasında yapısal olarak yer aldığı için aktörlerin yatkınlıklarını en derin boyutlarda belirlemesiyle ilişkilidir. Yine Bourdieu ve Passeron'un "Varisler"de "toplumsal eşitsizliklere ilişkin körlüklerin, tüm eşitsizlikleri ve özellikle de tedrisi (eğitim) başarıyla ilgili olanları, doğal eşitsizlikler, yani yetenek eşitsizlikleri olarak açıklamaya müsaade etmesi ve zorlaması" (2015: 107) simgesel düzenin ve sembolik şiddetin eşitsizlikleri saklamasının, tedrisi süreçler ve hukuksal dizgelerle inşacı devletin kurumsal ritüelleriyle iç içe geçmesiyle ilişkilidir.

Bedenlerin, zihinlerin ve duyguların yeniden üretildiği ve sağaltıma alındığı inşa edilmiş sosyal gerçeklikte, bireyler mesleklerini, eğitim düzeylerini, toplumsal kökenlerini, sınıfsal konumlanmalarını ve mülkiyet edinim süreçlerindeki verili durumlarını niçin öyle olduklarını sorgulamaksızın kabul ederler; daha doğrusu, bireylerin zihinlerine işlenen kodlar, yatkınlıklar biçimine dönüşür ve göz ardı edilme olasılığı çok sınırlı olan tunçtan toplumsal yasalarla inşa edilir. Örneğin, orta yaşlı bir işçi, niçin bir doktor, profesör, yazar ya da iş adamı olamadığını çok fazla sorgulamaksızın, kendi verili yazgısını içselleştirir ve bu yazgının yaşamsal sahiciliğini inşa ederek, en gerçekçi biçimde yaşar. Dışlanma süreçleri, simgesel düzen eşliğinde deneyimlenir ve benliğin en savunmasız aşamalarında (çocukluk) yatkınlıklara işleyerek habitusların ayrılmaz bir parçası olur. Bourdieu'ya göre dışlanma süreçleri, büyük inşacının (devletin) toplumsal gücü eşitsiz dağıtımının sonucudur. Simgesel düzen, dışlamalarla ve sosyo-ekonomik zorlamalarla ayakta durur. Böylece, siyasal sermayeyi 


\section{Cem ÖZKURT, "Toplumsallık, Anlam ve Bir Sosyal İnşa Olarak İnsan," Kaygı, 18(1)/2019: 154-171.}

elinde bulunduranlarla, bu sermayeye sahip olmayı tahayyül bile edemeyecekler arasındaki bilinç, farkındalık ve seziş mesafeleri kapatılamayacak bir biçimde açılır. Manipülasyona maruz kalmış zihin ve benlikler mimiklerini, jestlerini, seslerini, sözlerini, duygulanımlarını, algılarını ve hissedişlerini, dış dünyadaki eril manipülasyonlarla birlikte deneyimlerler ve speküle edilmiş, hakikatinden sıyrılmış benlikler "öyle ola geldiği haliyle” yaşamaya devam ederler.

Bourdieu'nun Ayrım'da İhtiyar bir marangozun kendiliğindenliğini vurguladığı pasaj, yatkınlıkların mesleki, sınıfsal ve tarihsel düzenliliklerinin aktörlerde oluşturduğu habitusların yaşamın sosyolojik bütünlüğüne içkin pratiklerini göstermesi bakımından dikkate değerdir:

İhtiyar bir marangozun dünya görüşü bütçesini zamanını veya bedenini idare etme biçimi, dili kullanımı ve kılık seçimi, onun titiz ve kusursuz zanaatkârlığındaki itinalı ve incelikli etiğinin yanı sıra ürettiklerinin güzelliğini gereken özen ve sabırla tartmasını sağlayan zanaat için zanaat estetiğinde bütünüyle mevcuttur. Leibniz'in vurguladığı gibi, yaşam stilinin her bir boyutu, diğer boyutları hem simgeler hem de -onlar- ile simgeler "' (Bourdieu 2015: 259).

Toplumsal uzamda ehlileştiren mekanizmalar, bizzat iktidar stratejilerinin ve toplumsal gücün difüzyonunun (yayılımının) belirli bir biçimde kanalize edilmesinin, hakikati bilme/anlama/yorumlama kategorilerinin ve epistemolojik meşruiyet araçlarının (kültürel sermaye) kanonlaştırılmasının sonucudur. Bourdieu, bunu "Dünyanın Sefaleti" isimli çalışmasında, ezilenlerin kendi ontolojik varoluşlarına sosyo-ekonomik bir anlamladırma yapmalarının ne düzeyde güç olduğunu vurgulayarak ifade eder. Bu toplumsal gruplar, alg1 kategorilerinin, yorumlama dayanaklarının, bilişsel çerçevelerin, söylemlerin ve retoriklerin kendilerinden olabildiğince uzak inşa edildiği ama olabildiğince de onlara iliştirildiği farklı türden bir durumsallıkla karşı karşıyadır: "Ezilenlerin söylemine çok az yer tanınıyorsa bu, söz konusu kesimlerin seslerinin bilhassa güç işitildiği içindir. Bu insanlar konuşmaktan çok konuşulurlar ve egemenlerle konuştuklarında da ödünç bir söylem kullanırlar: Tam da egemen grubun onlar hakkında konuşurken kullandığı söylemi (...)” (Bourdieu 2015: 108-109). 


\section{Toplumsal İfadelerin Anlamlılığı ve Pratiklerin Temsiliyeti}

Clifford Geertz, "Yoğun Betimleme:Yorumsal Bir Kültür Kuramına Doğru" makalesinde, bir etnografyacının sadece olay ağları ya da olmuş bitmiş şeylerin nasıl olduğunu değil de, onları meydana getiren yeterliliklerin farklı türden ilişkiler ağı gerektirdiğini ve bu ilişkilerin toplumsal ifadelerin anlamlarını ve gündelik pratiklerin kendine has ritmini yansıttığını ifade eder. Böyle bir temsiliyeti betimlemek açısından, 1912'de Fas'ın Marmusha bölgesinde yaşanmış bir olayı nakleder (olay, 1968'de bulunan şişe içerisinde bir kağıtta anlatılmaktadır). Marmusha bölgesi, Fransızların kontrolünde olan bir kasabadır. Yirmi kadar küçük karakolla güvenliği sağlamaya çalışan Fransızlar pek de başarılı olamamıştır. Bu nedenle de mezrag, yani ticaret anlaşması, yasal açıdan bozulmuş olsa da aynen daha önce olduğu gibi devam etmektedir. Bir gece Cohen'in (kendisi Berberi dilini akıcı konuşan Yahudi bir tüccardır) yanına, başka iki Yahudi mal almak için gelmiştir. Başka bir komşu kabileye ait Berberiler, Cohen'in yerine zorla girmek isteyince, Cohen, tüfeğiyle havaya açar (Aslında, Yahudilerin silah taşımaları yasaktır; ama o sıralar her yan öyle karışıktır ki birçok Yahudi yine de silah bulundurur) ve saldırganlar kaçar. Ancak, ertesi gece saldırganlar tekrar harekete geçer ve Cohen'in yanındaki iki arkadaşını öldürerek dükkandaki bütün malları çalarlar. Cohen, yaralı vaziyette, kaçarak canını zor kurtarır. Sonra şikayetini bildirmek için karakola gider ve Yüzbaşı Dumari adındaki yerel komutana şikayete bildirir; 'ar', yani ondan çalınan malın dört ya da beş kat fazlasını istediğini anlatır. Soyguncular henüz Fransız otoritesini kabul etmemişlerdir ve açık bir direniş sergilemektedirler. Cohen, mezrag gerçekleştirdiği Marmusha kabilesinin şeyhiyle birlikte, -kabile kurallarına göre, şeyh, mezrag gerçekleştirdiği tüccarın hasarını tazmin etmek zorundadır- karakola gider ve ne yapmak istediklerini anlatır. Ancak, Yüzbaşı Dumari bunun için resmi bir izin vermez çünkü mezrag ilişkisi Fransızlarca yasaklanmıştır. Ama sözlü olarak izin verir ve “ eğer öldürülürsen bu senin sorunun olur" der. Böylece şeyh, Yahudi ve silahlı adamları, isyancı bölgesine girerler. Gizlice yaklaşıp soyguncu kabilenin çobanını kaçırırlar. Çok kısa bir süre sonra 
soyguncu kabilenin üyeleri at sırtında peşlerine takılır. Soyguncu kabilenin üyeleri, koyun hırsızlarının kim olduklarını görünce şaşırırlar ve "Pekala konuşalım" derler ve böylece uzun bir pazarlık başlar. Soyguncu kabile, Marmushalarla ciddi bir kan davası başlatıp, işgalci güçlerin gözü önünde gelişigüzel çarpışmaya hazırlıklı değildir. İki grup uzunca bir pazarlıktan sonra verilen zarar karlı̆ı̆ında beş yüz koyun üzerinde anlaşır. Cohen, koyunlarını alır ve Marmusha'ya koyunlarıyla döner. Uzaklarda olsa da, Fransızlar yukarıdaki karakollarından onun gelişini işittiler ("Me, me, me" diyordur Cohen büyük bir mutlulukla, koyunlarını anımsayarak) ve Fransızlar, dediler ki, "Bu da ne demek oluyor?" Cohen de şöyle dedi: "işte bu benim ar." Fransızlar, Cohen'in anlattıklarına inanmadılar ve onu isyancı berberilerin casusu olmakla suçlayıp hapse attılar, koyunlarına da el koydular. Kasabada Cohen'den haber alamayan ailesi öldüğünü zannediyordu. Ama bir süre sonra Fransızlar tarafindan serbest birakıldı ve evine döndü fakat koyunları olmadan. Sonra kasabadaki Albaya, yani bütün yöreden sorumlu olan Fransız'a gidip şikayetini iletti. Ama Albay ona şöyle dedi: "Bu konuda hiçbir şey yapamam. Benim sorunum değil” (2010: 22-23).

Geertz'in etnografik duyarlıklarla naklettiği bu olay, toplumsal ifadelerin anlamlllığı ve gündelik pratiklerin çok yönlü temsiliyeti bakımından dikkate değerdir. Geertz'e göre bu olay ağı ile ilgili olarak sorulması gereken soru: "anlamlarının ne olduğudur." Yani bu olay ağı, alay $\mathrm{m}$, meydan okuma $\mathrm{m}$, alaysılama $\mathrm{m}$, hiddet mi, züppelik mi, gurur mu içermektedir? (2010: 25) ya da birbirine uzak olmayan nesnel ilişki ağının bir çeşit konfigürasyonları olarak $\mathrm{m} ı$ algılanmalıdır? $\mathrm{Bu}$ sorular çerçevesinde değerlendirildiğinde, Geertz'in analizi şöyledir: "Fas'ta bir ticaret anlaşması yapabilmek için belirli şeyleri belirli yollardan yapabilmeli (örneğin, bir yandan Kuran'dan Arapça sureler söylerken bir yandan da kabilenizin bir arada toplanmış dindar erkek üyelerinin gözleri önünde bir kuzunun boğazını kesebilmelisiniz) ve belirli psikolojik niteliklere (her şeyden önce, uzaklardaki şeylere yönelik bir arzuya) sahip olmalısınız. Koyun çalmanın ne demek olduğunu bilmeden ve bunu nasıl gerçekleştireceğinizi bilmeden koyunlara baskın düzenleyemez ya da düzenlermiş gibi yapamazsınız (2010: 27). 


\section{Cem ÖZKURT, "Toplumsallık, Anlam ve Bir Sosyal İnşa Olarak İnsan,” Kaygl, 18(1)/2019: 154-171.}

Geertz, Cohen, şeyh ve Yüzbaşı Dumari arasındaki birbiriyle kesişen ilişkiler ağını, her biri kendi kulvarında mevkilerini güçlendirmeye çalışan, kendi pratikleri içinde boğumlanan ve içeriklenen etkileşimi toplumsal bir yapılaşma olarak değerlendirir. Bu etkileşimsel yapılaşmada aktörler, konumlanmalarını pratikler yoluyla güçlendirmeye çalışırlar:

Kültürel biçimler elbette boğumlanmayı çeşitli ürün biçimlerinde ve çeşitli bilinç düzeylerinde bulunmakta; fakat bunlar anlamlarını birbirleri arasında taşıdıkları her hangi bir özünlü ilişkiden değil, süregelen yaşam biçimlerinde oynadıkları (Wittgenstein olsa "kullandıkları" derdi) rolden almaktadır. Cohen, şeyh ve Yüzbaşı Dumari'nin birbirlerinin amaçlarına karıştıklarında yaptıkları da aynen buydu- ticaret peşinde koşmak, onurlarını korumak, egemenlik sağlamak; bu da gözlerimizin önündeki pastoral dramayı oluşturuyordu (2010: 33).

Geertz, bu pastoral dramayı, daha açık bir dille ifade eder: "Kendisine ait 'ar üzerinde hakkını savunarak Cohen, bir ticaret anlaşmasını harekete geçirdi; savunulan hakk1 kabullenen şeyh, hakkı çiğneyenlere meydan okudu; sorumluluğu kabullenen karşı kabile tazminat ödedi; hem şeyhlere hem de tüccarlara buralarda kimin efendi olduğunu gösterme endişesi taşıyan Fransızlar emperyalist yüzlerini gösterdi” (2010: $34)$.

\section{Sonuç Yerine}

Hem bireylerin gündelik algı dünyasının hem de toplumsallığın kendine özgü dinamik işleyişinin ayrılmaz parçaları olan simge, sembol ve anlam temelli sosyo-psişik kök inşalar; belirli bir tarihsel sürekliliğin ve ekonomik, siyasal, kültürel yaşanmışlıklar evreninin geçmiş ve bugün arasındaki tortulaşmış bir kimliğidir ve bu kimlik, bireylerin biyografik yaşantılarından öte bir biçimde ve hala hazırda sosyolojik olarak kuruludur. Bize ve bize özgü olduğunu zannettiğimiz düşünceler, kanaatler, tutumlar, hissedişler, duraksamalar, jestler, mimikler ve duygulanımlar sosyal olarak inşa edilmiş gerçekliğin ve bu gerçeklikteki tarihsel olarak kurulu ve aynı zamanda da dinamik olan toplumsal güç ilişkileri ağının ürünüdür. 
Toplumsal güç ilişkilerinin dağılımı ve istikameti, gündelik yaşantılarda sadece sınıf konumlarını, statüyü ve maddi/nesnel sosyo-ekonomik zorunluluklar evrenini belirlemekle kalmamakta; aynı zamanda, biçimlenişleri ve ayrıntıları konjenktürel olan zamana, mekâna ve koşullara göre değişen toplumsal düzeyli davranım, düşünme ve duygulanım kalıplarını da inşa etmektedir. Toplumsal güç ilişkilerinin biçimlendirdiği ve şekil verdiği bu kalıplar, gündelik işleyiş ve pratiklerde alanlarda ya da toplumsal karşılaşmalarda toplumun sosyo-ekonomik dizgelenme ve sıralanma biçimleriyle tutarlıdır ve zihinleri bir eğilim olarak kategorileştirme ve dışlamalarla tahayyül etmeye sevk etmektedir.

Geertz'in Bali yerlilerinin horoz döğüşlerini analiz ettiği makalesinde, horoz döğüşünün erksi heyecanını inşa eden oyunun merkeziyle, bu heyecana göre konum olan çevrenin davranışsal, düşünsel ve duygusal eşleşmesi, kalıpların örtüşmesinin müstesna bir örneğidir. Gerçek yaşamdaki para, statü ve prestij opaklaşmasının merkezi, (failler düzeyinde) toplumun da merkezidir ve düşünme, davranma ve duygulanma kalıplarının üretimi de bu merkezden yapılmaktadır. Çevrenin (sosyo-ekonomik olarak daha geride olanlar) düşünsel ve duygusal alg//hissetme kategorileri ise merkezin biçimlendirdiği bu kalıplara göre konum almaktadır.

Gündelik yaşamın en temel insansal ögelerini oluşturan merhamet, iyilik, kardeşlik, eşlik, dostluk gibi Durkheim'da da toplumu birbirine bağlayan ve bir toplumsal zamk işlevi gören tinsel ögeler, toplumsal kalıpların nitelik, öz ve kimlikleriyle örtüşüp örtüşmediğine göre yaşama geçer ve pratiğe yansır. Eğer, toplumsal kalıplar rekabetçi bir dünyayı, statü için erk üretimini ya da homo economicusun kendini sağaltıma almak için stratejiler ürettiği bir evreni teşvik ediyorsa, tinsel ögeler (kardeşlik eşlik, dostluk) sahiciliğini yitirir ve toplumsal yaşamdaki basit stratejilerin leitmotifine (itici güç) dönüşür. Bu yönlü bir toplumsal durumsallık, simge, sembol ve anlam örtüntülerinin de yönünü tayin eder ve onlara biçim verir.

Burada dikkat edilmesi gereken nokta, toplumsal durumsallıklar içerisinde tarihsel karakterli olarak olgunlaşan simge, sembol ve anlam ağlarının pozitif ya da negatif 
değerlilikleri değil; "sosyolojik bir nesnellik" olarak güç ilişkilerine gömülü mahiyeti ve bireylerin düşünsel, duygusal ve davranışsal doğalarını inşa edilmiş kimlikler biçiminde, toplumsal olarak yeniden üretmesi ve aynı zamanda, bireyleri doğumlarından ölümlerine kadar kompoze eden örüntüsel bir toplumsal oluş olmalarıdır. 


\section{KAYNAKÇA}

ALTHUSSER, Louis (2014). İdeoloji ve Devletin İdeolojik Aygitları, çev. Alp Tümertekin, İstanbul: İthaki Yayınlar.

ARON, Raymond (2014). Sosyolojik Düşüncenin Evreleri, çev. Korkmaz Alemdar, İstanbul: Kırmızı Yayınları.

BERGER, John (2013). Görme Biçimleri, çev. Yurdanur Salman, İstanbul: Metis Yayınları.

BERGER, Peter L. \& Thomas LUCKMANN (2008). Gerçekliğin Sosyal İnşası, çev. Vefa Saygın Öğ̈̈tle, İstanbul: Paradigma Yayınları.

BOURDIEU, Pierre (2006). Pratik Nedenler, çev. Hülya Uğur Tanrı̈öer, İstanbul: Hil Yayınları.

BOURDIEU, Pierre (2014). Düşünümsel Bir Antropoloji İçin Cevaplar, çev. Nazlı Ökten, İstanbul: İletişim Yayınları.

BOURDIEU, Pierre (2015). Eril Tahakküm, çev. Bediz Yılmaz, İstanbul: Bağlam Yayınları. Yayınlar1.

BOURDIEU, Pierre (2015b). Devlet Üzerine, çev. Aslı Sümer, İstanbul: İletişim

BOURDIEU, Pierre \& J. C. PASSERON (2015c). Yeniden Üretim, çev. Aslı Sümer, Levent Ünsaldı ve Özlem Akkaya, Ankara: Heretik Yayınları.

BOURDIEU, Pierre \& J. C. PASSERON (2015d). Varisler, Öğrenciler ve Kültür, çev. Aslı Sümer ve Levent Ünsaldı, Ankara: Heretik Yayınları.

BOURDIEU, Pierre (2015e). Ayrım, çev. Derya Fırat Şannan ve Ayşe Günce Berkkurt, Ankara: Heretik Yayınları.

BOURDIEU, Pierre vd. (2015f). Dünyanın Sefaleti, çev. Levent Ünsaldı vd., Ankara: Heretik Yayınları. Heretik Yayınları.

BOURDIEU, Pierre (2016). Seçilmiş Metinler, çev. Levent Ünsaldı, Ankara:

COSER, A. Lewis (2011). Sosyolojik Düşüncenin Ustalarl, çev. Himmet Hülür, Serhat Toker ve İbrahim Mazman, Ankara: De ki Basım Yayım.

DURKHEIM, Emile (1994). Sosyolojik Metodun Kurallarl, çev. Enver Aytekin, İstanbul: Sosyal Yayınları.

DURKHEIM, Emile (2006). Toplumsal İşbölümü, çev. Özer Ozankaya, İstanbul: Cem Yayınevi. 
GEERTZ, Clifford (2010). Kültürlerin Yorumlanması, çev. Hakan Gür, Ankara: Dost Kitabevi Yayınları.

GIDDENS, Anthony (2014). Kapitalizm ve Modern Sosyal Teori, çev. Ümit Tatlıcan, İstanbul: İletişim Yayınları.

GOFFMAN, Erving (2014). Damga, çev. Ş. Geniş, L.Ünsaldı ve S. N. Ağırnaslı, Ankara: HERERİK Yayınları.

MEAD. H. G. (2017). Zihin, Benlik ve Toplum, çev. Yeşim Erdem, Ankara: Heretik Yayınları. 